GERAN-MARKO MILETIĆ, Ph.D. ${ }^{1}$

E-mail: geran@pilar.hr

SLAVEN GAŠPAROVIĆ, Ph.D. ${ }^{2}$

E-mail: slaveng@geog.pmf.hr

TONČI CARIĆ, Ph.D. ${ }^{3}$

(Corresponding author)

E-mail: tonci.caric@fpz.hr

${ }^{1}$ Institute of Social Sciences Ivo Pilar

Marulićev trg 19/I, 10000 Zagreb, Croatia

2 University of Zagreb, Faculty of Science, Department of Geography, Marulićev trg 19/II, 10000 Zagreb, Croatia

${ }^{3}$ University of Zagreb, Faculty of Transport and Traffic

Sciences, Vukelićeva 4, 10000 Zagreb, Croatia
Traffic Policy

Preliminary Communication

Submitted: 8 July 2016

Accepted: 8 Feb. 2017

\title{
ANALYSIS OF SOCIO-SPATIAL DIFFERENTIATION IN TRANSPORT MODE CHOICE PREFERENCES
}

\begin{abstract}
Starting from the fact that the transport mode choice is one of those aspects of travel behaviour that, to a great extent, affects the efficiency of the transport system, this paper analyses the factors that contribute to the use of public and car transport. The goals of the analysis were to obtain insight into the preferences for using these two modes of transport in Croatia and find out to which extent the basic demographic and socioeconomic characteristics of the respondents affect the usage of car and public transport and the possibility of taking trips by these transport modes. The paper analyses the data collected by surveys on a representative national sample. The results show that in Croatia, the number of people who frequently use public transport is far fewer than the number of frequent users of passenger car transport. However, the comparison has found that the number of frequent public transport users varies significantly among certain categories of respondents. Using binary logistic regression analysis has determined that the preferences towards the frequent use of car or public transport are significantly influenced by the age of the respondents, size of the settlement, accessibility of the destinations by public transport, the number of vehicles in the household and whether the respondent is the main car user in the household.
\end{abstract}

\section{KEY WORDS}

mobility; travel behaviour; transport mode choice; public transport; car transport;

\section{INTRODUCTION}

In recent decades, the people's level of mobility has increased in almost all European states. As consequence, there are certain problems, such as traffic congestion, environmental pollution, etc. [1]. However, the increase in mobility has also caused certain changes in the society. Thus, among other things, there are changes in the lifestyle of people, which eventually leads to different travel needs, i.e. travel behaviour.

The issue of travel behaviour is extremely complex since it is affected by a number of different factors. The study of the travel behaviour of individuals is extremely important in transport planning and in defining transport policies. The study and comparison of different factors that affect the travel behaviour of an individual make it possible for transport planners to isolate the most significant factors, thus helping efforts to improve the transport systems and the people's quality of lives [2].

The complexity of travel behaviour is also reflected in the transport mode choice in every trip. Here, every transport mode has its characteristics, advantages, drawbacks and costs. The transport mode choice will depend on a number of factors. They may vary over time, and they will depend on the type of the trip. There are no unambiguous guidelines of preferences for using certain modes of transport, but the transport mode choice is usually the result of a complex interaction of several different elements, such as characteristics of the participants themselves, travel purposes, the location of the origin and destination, as well as the characteristics of the space in which the travel is performed [1]. The study of the influence of individual factors on the use of different transport modes has certain traditions in Croatia as well. There are, for instance, studies that focus on the use of certain transport modes for personal trips, such as public transport or bicycle $[3,4]$. However, there is a lack of analysis that offers insights into the use of car transport, and there is also lack of empirical studies that would give a comparative insight into the usage of transport modes in the Croatian society.

This paper will try to contribute to the understanding of one segment of the travel behaviour in the Croatian society. The focus of the research is directed 
to the interrelation of using car and public transport, and the general goal is to determine to what extent the transport mode choice can be explained by the influence of different factors. Two specific goals of research result from the general goal. The first goal is to find out whether there are differences in the preferences of using car and public transport among certain categories of the population in Croatia. The second goal is to gain insight into the level to which the differences in the possibility of taking trips by public and car transport influence the preference for their usage.

The first part of the paper presents the theoretical base and the research methodology, the second part presents the results of analysis, and the discussion indicates the basic findings of the research. The paper ends with a conclusion.

\section{THEORETICAL BASIS OF RESEARCH}

As the basic human activity and need, mobility is usually interpreted as the possibility of the movement of people, i.e. as physical movement, and it is often mentioned in the context of human rights and freedoms [5, 6, 7]. The physical movement, i.e. physical travelling of people is usually connected with the term of mobility, although there are other forms of mobility (e.g. virtual mobility). Mobility of people is mostly affected by two groups of factors. Social factors refer to the characteristics of people and their needs, such as age, gender, property status, level of education, personal characteristics, etc. The other group of factors are physical factors that include the availability of certain types of transport for use, their adequacy for usage, characteristics of the space in which travel occurs, the destinations and the characteristics of travelling [8].

Mobility is an extremely important component in everyday life. Apart from the possibility of movement, mobility can also be considered in the context of enabling the meeting of different socioeconomic, cultural, political and other needs. These needs are often spatially distributed and therefore it is necessary to travel in order to reach them and at the same time selecting the transport mode. A series of different factors still influence the patterns, complexity and frequency of such travelling, including the transport mode choice [9].

Many authors address the issues of determinants of the transport mode choice, as e.g. [2, 8, 10, 11] indicating an entire series of determinants that may be classified into three groups:

a) Subjective determinants that include socioeconomic and demographic determinants, attitudes and perceptions as well as the lifestyle of individuals;

b) Spatial determinants; c) Determinants of transport policy and law.

The incomes of individuals, i.e. households and the ownership of cars are the usual factors that are mentioned in the studies of the transport mode choice [10]. These two factors are connected, and higher incomes allow also for easier use and maintenance of cars, including more frequent use $[12,13]$. Apart from these factors, this group also includes factors such as physical condition of the individual, gender, age and composition of the household [14]. For example, the transport mode will be limited for children who will have to opt for public transport or will depend on others for transport (e.g. on parents, friends, taxi) [15]. Further, this group also includes factors such as attitudes and perception of the individual, such as attitude and perception of safety, attitude towards adequacy, i.e. attractiveness of a certain transport mode, ecological awareness of the individual, attitude about the value of time and money, etc. Thus, for instance, school female students will use taxi for an evening out more often than school male students, precisely because it offers a feeling of greater safety than using public transport at night [15]. People's lifestyles can also influence the transport mode choice. This determinant is sometimes connected to the influence of culture in which the individual lives and is therefore called a cultural determinant [12]. Thus, one can distinguish between people who consider the car as a status symbol and method of free movement and people who are forced to have and use a car for other reasons (e.g. poor public transport) [16].

Spatial determinants of the transport mode choice usually include functional and morphological structure of the settlement (usually the building density and the form of the neighbourhood) and land use [17, 18]. They can influence the time, costs, accessibility and adequacy of using a certain transport mode [19]. Settlements with rural characteristics and settlements with lower building density will be farther away from the space with a higher concentration of services (e.g. school, hospital, theatre), and more time will be needed to access such spaces in relation to the cities and spaces with a higher population density. The citizens of these settlements will have to use a car more frequently in relation to the population in urban areas who have better options to use public transport, bicycles or to walk. This supports better development of traffic infrastructure in urban settlements, such as better development of cycling paths, better construction of pavements and the like $[10,14,16]$. Eventually, this may lead to an increase in traffic costs related to fuel consumption and car maintenance [20].

Transport policies and laws can also influence the transport mode choice. For example, fuel prices, highway tolls, parking prices, speed limits and taxes may influence the transport mode choice. Besides, transport policies that stimulate the use of public transport, 
cycling or walking, while at the same time limiting travel by car, can influence people's transport mode choice [21].

\section{METHODOLOGY}

The data used in the analysis were collected through a survey carried out by the Institute of Social Sciences Ivo Pilar from September to November 2014. Paper-and-pencil interviews (face-to-face) were used as the mode of data collection. The target population were the citizens of Croatia aged 14 and older. The survey was carried out on a multistage, stratified, probabilistic sample of 3,000 respondents in 249 settlements. The primary sampling units were settlements, the secondary sampling units were street addresses, the tertiary sampling units were households, and in the last stage, the quaternary sampling units were the individuals. In the first stage, the selection of the primary sampling units was stratified using the following characteristics: region, type and size of the settlement. Combinations of these three characteristics produced 24 different strata, and the sample size of each stratum was proportionate to its population size. The deviation of the realised sample from the population values has been corrected by using weights, thus ensuring its representativeness at the national level for the criteria of gender, age and education.

The introduction indicated that the analysis of factors related to the transport mode choice focused on specific travel behaviour, specifically on the interrelation of using passenger cars and public transport. Hence, only the travel patterns of frequent car or public transport users will be the focus of this study. The research goal set in this way directed the analysis only to a part of the respondents, that is, to those who at least theoretically have the possibility of choice. Therefore, the analysis has included only those respondents who come from households that have a car at their disposal.

Furthermore, distinguishing preferences regarding the use of cars and public transport is based on the reported frequency of their usage. The frequencies of using cars (as driver or passenger) and some form of public transport (tram, bus, rail or ship) have been measured for the last year on a scale of seven grades. The first grade of the scale that refers to the most frequent usage of transport (three or more times a week) has been used as the criterion to distinguish the respondents regarding their preferences for the usage of car or public transport.

Figure 1 shows the procedure of selecting the final set of data regarding the two parameters. This procedure resulted in a sub-sample with a total of 1,686 respondents who were included in further analysis.

Since the research focuses on two types of travel behaviour, on the one hand the dominant usage of car-only transport, and on the other hand the dominant usage of public transport (independently or in combination with a car), the typology applied in the analysis is based on the frequency of using car and/ or public transport by distinguishing the following two categories of respondents:

1) Frequent car-only users - includes people who use car transport three or more times a week, and use public transport less frequently or never $(N=1,316)$;

2) Frequent public transport users - includes people who use public transport three or more times a week, regardless of how often they use a car $(N=370)$.

In order to determine that the two created groups of respondents really differ regarding the tendency to use public transport, data was also collected and analysed regarding all trips people took the day preceding the survey. The analysis showed the existence of statistically significant differences in which the frequent car-only users, out of all the recorded trips about $2 \%$ were performed by public transport, whereas the frequent public transport users, out of all the recorded trips almost half of them used public transport $(49.7 \%)$. Thus, these are two groups that have clearly different travel behaviour patterns, which shows the satisfactory validity of the selected criterion for differentiating people regarding the frequency of using public or car-only transport.

The analysis used as independent variables the basic sociodemographic and socioeconomic characteristics of respondents (gender, age) and their households (respondents' subjective evaluation of household standard of living and whether they have children younger than 14 in the household), then the indicators that show the availability of the public transport network (size of settlement, distance to the nearest public transport stop from the residential address and the accessibility of usual destinations by public transport)

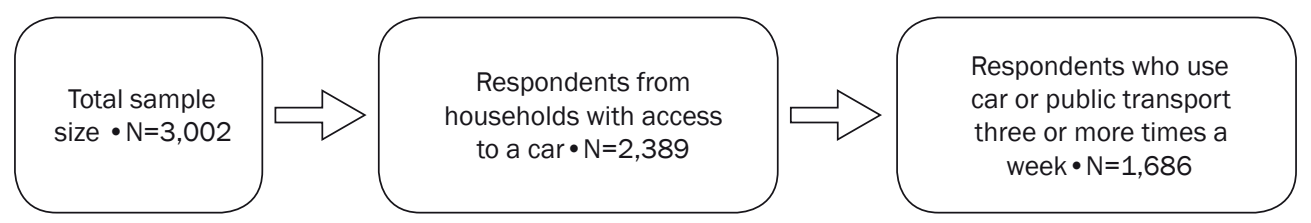

Figure 1 - Weighted frequencies for key variables used in the selection of a final set of data $(N=3,002)$ 
and about the availability of car transport (number of cars in the household and whether a person is the main user of the car).

Operationalisation of the public transport network availability in the analysis followed a simple logic of the users. The attempt was, namely, to determine whether both the origins and the destinations of trips are accessible by public transport and whether the person lives in an area that is more densely networked by public transport. The mentioned third element was included indirectly through the size of the settlement. Concerning the settlement size, it should be noted that, according to the 2011 Census, the majority of Croatian citizens live in small and medium-sized settlements, and there are only four settlements with more than 75,000 inhabitants. And only in these four large urban centres does public transport, through its number of lines and frequency of transport, have the potential to provide high-quality alternative for car transport. Therefore, the respondents have been classified regarding the size of the settlement in two categories, and the border value is 75,000 citizens. The main characteristics of the analysed sample are shown in Table 1.

Table 1 - Analysed sample characteristics $(N=1,686)$

\begin{tabular}{||l|l|c||}
\hline \multicolumn{2}{|c|}{ Variables } & $\%$ \\
\hline \hline \multirow{4}{*}{ Age } & Male & 54.7 \\
\cline { 2 - 3 } & Female & 45.3 \\
\hline \multirow{3}{*}{$\begin{array}{l}\text { Subjective evaluation of house- } \\
\text { hold standard of living }\end{array}$} & $14-29$ & 27.2 \\
\cline { 2 - 3 } & $30-64$ & 65.3 \\
\cline { 2 - 3 } & $65+$ & 7.5 \\
\cline { 2 - 3 } Households with children & Average & 68.4 \\
\hline younger than 14 & Above average & 8.5 \\
\hline \multirow{3}{*}{ Settlement size } & No & 63.9 \\
\cline { 2 - 3 } & Yes & 36.1 \\
\hline \multirow{2}{*}{ Nearest public transport stop } & $<75,000$ & 74.4 \\
\cline { 2 - 3 } & $>75,000$ & 25.6 \\
\hline \multirow{2}{*}{$\begin{array}{l}\text { Accessibility of usual } \\
\text { destinations by public transport }\end{array}$} & $<=5$ min. & 38.4 \\
\hline \multirow{2}{*}{ Number of cars in a household } & Yes & 61.6 \\
\hline \multirow{2}{*}{ Main driver of household car } & 1 & 19.4 \\
\cline { 2 - 3 } & 2 or more & 80.6 \\
\cline { 2 - 3 } & No & 62.3 \\
\hline \hline
\end{tabular}

In the first step, by using the chi-square test, the statistical significance of the differences in preferences towards frequent usage of car-only or public transport, was analysed regarding the indicated independent variables. In the second step, the hierarchical binary logistic regression analysis was used to create a model that enabled insight into the structure of the interrelation of independent variables and the relative influence of each of them on the likelihood that a person is a frequent user of public or car-only transport. All the mentioned analyses were carried out using IBM SPSS 23 software.

\section{RESULTS}

\subsection{Differences in preference for car-only versus public transport use}

The comparison of usage preferences of the two analysed modes of transport reveals that the respondents are much less likely to use public than car-only transport (Figure 2). More precisely, the distribution of respondents in two categories shows that only $21.9 \%$ were in the category of frequent public transport users, whereas $78.1 \%$ were in the category of frequent car-only users. These shares reveal that a person from a household that has a car available is $72 \%$ less likely to use public transport three or more times a week than using equally frequently car-only transport.

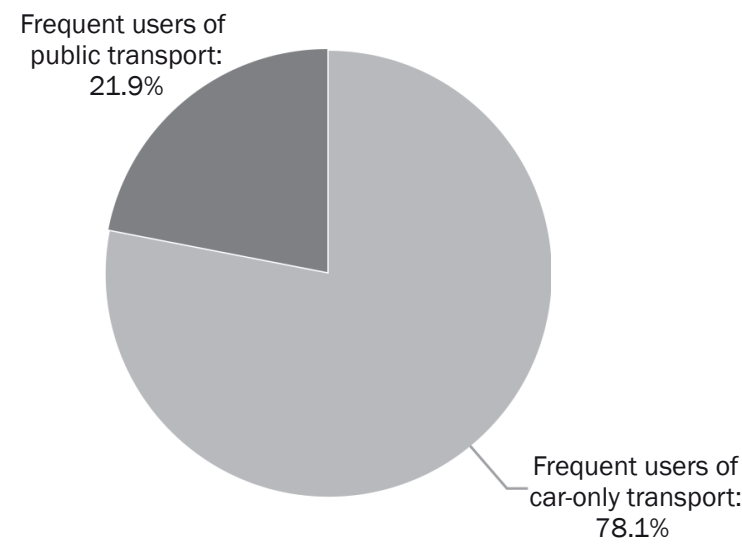

Figure 2 - The share of frequent users of public transport and frequent users of car-only transport $(N=1,686)$

Further analysis focuses on a pattern of frequent use of public or car-only transport. For that purpose, the differences in usage of these two transport modes regarding the selected sociodemographic and socioeconomic characteristics and also regarding the availability of these two modes of transport were analysed.

The results from Table 2 reveal that among the four analysed sociodemographic and socioeconomic variables (gender, age, subjective evaluation of household standard of living and household composition), only the variable that describes the economic status of the household was not statistically significantly related to the differences in the share of frequent users of public or car-only transport. The analysis showed 
Table 2 - The share of frequent car-only and public transport users regarding the basic sociodemographic and socioeconomic characteristics and availability of transport

\begin{tabular}{|c|c|c|c|c|}
\hline \multicolumn{2}{|l|}{ Variables } & $\begin{array}{l}\text { Frequent users of } \\
\text { car-only transport [\%] }\end{array}$ & $\begin{array}{l}\text { Frequent users of } \\
\text { public transport [\%] }\end{array}$ & Pearson $\chi^{2}$ \\
\hline \multirow{2}{*}{ Gender } & Male & 83.9 & 16.1 & $41.812 * *$ \\
\hline & Female & 70.8 & 29.2 & \\
\hline \multirow{3}{*}{ Age } & $14-29$ & 48.6 & 51.4 & $320.867 * *$ \\
\hline & $30-64$ & 89.7 & 10.3 & \\
\hline & $65+$ & 83.3 & 16.7 & \\
\hline \multirow{3}{*}{$\begin{array}{l}\text { Subjective evaluation of household } \\
\text { standard of living }\end{array}$} & Below average & 77.3 & 22.7 & 0.852 \\
\hline & Average & 78.1 & 21.9 & \\
\hline & Above average & 81.0 & 19.0 & \\
\hline \multirow{2}{*}{$\begin{array}{l}\text { Households with children younger than } \\
14 \text { years }\end{array}$} & No & 76.1 & 23.9 & $6.398 *$ \\
\hline & Yes & 81.4 & 18.6 & \\
\hline \multirow{2}{*}{ Settlement size } & $<75,000$ & 85.3 & 14.7 & $151.106 * *$ \\
\hline & $>75,000$ & 56.9 & 43.1 & \\
\hline \multirow{2}{*}{ Nearest public transport stop } & $>5 \min$ & 83.0 & 17.0 & $15.964 * *$ \\
\hline & $<=5 \mathrm{~min}$ & 74.6 & 25.4 & \\
\hline \multirow{2}{*}{$\begin{array}{l}\text { Accessibility of usual destinations by } \\
\text { public transport }\end{array}$} & No & 93.7 & 6.3 & $58.454 * *$ \\
\hline & Yes & 73.8 & 26.2 & \\
\hline \multirow{2}{*}{ Number of cars in a household } & 1 & 74.4 & 25.6 & $21.236 * *$ \\
\hline & 2 or more & 84.0 & 16.0 & \\
\hline \multirow{2}{*}{ Main driver of household car } & No & 52.0 & 48.0 & $380.383 * *$ \\
\hline & Yes & 93.0 & 7.0 & \\
\hline
\end{tabular}

$\star p<0.05 \quad \star * p<0.01$

that among females, there are more frequent public transport users than among males $(29.2 \%$ and $16.1 \%$, respectively). Regarding the age of the respondents, the analysis showed that in three age categories, the category of 30-64 years of age had the fewest frequent users of public transport, whereas the category of 14-29 years had the largest number of public transport users (10.3\% and 51.4\%, respectively). Furthermore, the analysis showed that among people who come from households without children younger than 14, there are more frequent public transport users than among people who come from households with children younger than 14 years of age (23.9\% and $18.6 \%$, respectively).

The results of the chi-square test also showed a statistically significant difference in frequent usage of public or car-only transport regarding the availability of these two modes. Concretely, there are more frequent users of public transport among persons who live in large urban centres (towns with more than 75,000 citizens) than among those who live in towns with fewer than 75,000 citizens ( $43.1 \%$ and $14.7 \%$, respectively). Furthermore, there were more frequent users of public transport among people who have a public transport stop within 5 minutes from their residence than among those who have the nearest stop at a distance farther than a 5-minute walk $(25.4 \%$ and $17.0 \%$, respectively). The accessibility of the most common destination via public transport has also been connected with the differences in transport mode preferences; among respondents whose most common destinations are accessible by public transport, there are more frequent users of public transport than among people for whom the most common destinations are not accessible by public transport $(26.2 \%$ and $6.3 \%$, respectively). A greater share of frequent public transport users has been recorded among people whose household has only one car than among households in which two or more cars are available (25.6\% and $16 \%$, respectively). Also, the circumstance in which a person is the main driver of a household car has been related to the use of public transport; among the respondents who are not the main household car driver there are more frequent public transport users than among the main drivers of the household car (48.0\% and $7.0 \%$, respectively).

\subsection{Predictors of car-only versus public transport use}

In order to determine how much effect each independent variable has on the frequency of using public or car-only transport while controlling other independent variables, a hierarchical binary logistic regression has been carried out. The odds ratio of being a frequent user of public or car-only transport has been analysed by using three blocks of variables. This approach, based on the sequential entering of blocks of variables, allows us, roughly, to compare the effect that each block separately has on the analysed transport preferences. 
The first block included sociodemographic and socioeconomic variables; in the second block were variables that refer to the possibility of taking a trip by public transport and the third block included variables that refer to the possibility of taking a trip using car transport.

The summary indicators of the goodness of fit of the statistical model used to estimate the odds ratio of being a frequent user of public or car-only transport can be found in Table 3. The level of statistical significance for the likelihood ratio test and Hosmer-Lemeshow test shows that independent variables used in the model have good predictability for the dependent variable, whereas the number of standard errors does not indicate the existence of multi-colinearity among the used independent variables. The coefficient of determination (pseudo R2) in the final step (with all three blocks of independent variables) was 0.500 , which indicates a moderately strong correlation between the set of independent variables and the dependent variable. In the first step, the coefficient of determination was 0.271 , whereas after the second block was entered, the coefficient of determination was 0.383 .

The coefficient of determination obtained with the first block by including only the sociodemographic and socioeconomic variables indicates decent-sized effects of the selected variables on the odds of being a frequent user of public or car-only transport. In the first step, the odds are influenced by the age of the respondent; persons from the ages of 14 to 29 are most likely to be frequent users of public transport. Gender is also a statistically significant predictor - females are more likely to be frequent users of public transport than males - as well as the living standard of a household - people who think that the living standard of their household is below average are more

Table 3 - Results of binary logistic regression analysis (dependent variable: $0=$ frequent user of car-only transport; $1=$ frequent user of public transport)

\begin{tabular}{|c|c|c|c|c|c|c|c|c|c|c|}
\hline \multirow{2}{*}{\multicolumn{2}{|c|}{ Variable }} & \multicolumn{3}{|c|}{ Step 1} & \multicolumn{3}{|c|}{ Step 2} & \multicolumn{3}{|c|}{ Step 3} \\
\hline & & \multirow[t]{2}{*}{ S.E. } & \multirow[t]{2}{*}{ Wald } & \multirow[t]{2}{*}{$\operatorname{Exp}(B)$} & \multirow[t]{2}{*}{ S.E. } & \multirow[t]{2}{*}{ Wald } & \multirow[t]{2}{*}{$\operatorname{Exp}(B)$} & \multirow[t]{2}{*}{ S.E. } & \multirow[t]{2}{*}{ Wald } & \multirow[t]{2}{*}{$\operatorname{Exp}(B)$} \\
\hline \multirow{2}{*}{ Gender } & male & & & & & & & & & \\
\hline & female & 0.137 & $31.425^{* *}$ & 2.157 & 0.146 & $25.249^{* *}$ & 2.080 & 0.167 & 1.004 & 1.183 \\
\hline \multirow{3}{*}{ Age } & $14-29$ & & & & & & & & & \\
\hline & $30-64$ & 0.144 & $236.520^{* *}$ & 0.109 & 0.158 & $216.187^{\text {** }}$ & 0.098 & 0.173 & $103.907^{* *}$ & 0.171 \\
\hline & $65+$ & 0.268 & $37.373^{* *}$ & 0.194 & 0.289 & $38.395^{* *}$ & 0.167 & 0.323 & $22.237^{* *}$ & 0.218 \\
\hline \multirow{3}{*}{$\begin{array}{l}\text { Subjective } \\
\text { evaluation of } \\
\text { household } \\
\text { standard of living }\end{array}$} & $\begin{array}{l}\text { Below } \\
\text { average }\end{array}$ & & & & & & & & & \\
\hline & Average & 0.162 & 3.993* & 0.723 & 0.171 & $6.542^{*}$ & 0.646 & 0.186 & 2.195 & 0.759 \\
\hline & $\begin{array}{l}\text { Above } \\
\text { average }\end{array}$ & 0.282 & 3.311 & 0.599 & 0.310 & $9.527^{* *}$ & 0.384 & 0.337 & 3.191 & 0.547 \\
\hline \multirow{2}{*}{$\begin{array}{l}\text { Households with } \\
\text { children younger } \\
\text { than } 14 \text { years }\end{array}$} & No & & & & & & & & & \\
\hline & Yes & 0.150 & 0.665 & 0.885 & 0.158 & 0.006 & 1.012 & 0.171 & 0.004 & 0.989 \\
\hline \multirow{2}{*}{ Settlement size } & $<75,000$ & & & & & & & & & \\
\hline & $>75,000$ & & & & 0.162 & $89.868^{* *}$ & 4.633 & 0.182 & $89.444^{* *}$ & 5.596 \\
\hline \multirow{2}{*}{$\begin{array}{l}\text { Nearest public } \\
\text { transport stop }\end{array}$} & $>5$ min. & & & & & & & & & \\
\hline & $<=5 \min$ & & & & 0.163 & 0.010 & 1.016 & 0.177 & 0.090 & 1.055 \\
\hline \multirow{2}{*}{$\begin{array}{l}\text { Accessibility of } \\
\text { usual destinations } \\
\text { by public transport }\end{array}$} & No & & & & & & & & & \\
\hline & Yes & & & & 0.270 & $16.674^{* *}$ & 3.017 & 0.282 & $13.326^{* *}$ & 2.795 \\
\hline \multirow{2}{*}{$\begin{array}{l}\text { Number of cars in } \\
\text { a household }\end{array}$} & 1 & & & & & & & & & \\
\hline & $\begin{array}{l}2 \text { or } \\
\text { more }\end{array}$ & & & & & & & 0.175 & $5.304^{*}$ & 0.669 \\
\hline \multirow{2}{*}{$\begin{array}{l}\text { Main driver of a } \\
\text { household car }\end{array}$} & No & & & & & & & & & \\
\hline & Yes & & & & & & & 0.183 & $130.322^{* *}$ & 0.124 \\
\hline \multicolumn{2}{|l|}{$-2 \mathrm{LL}$} & \multicolumn{3}{|c|}{$1,377.235$} & \multicolumn{3}{|c|}{$1,228.385$} & \multicolumn{3}{|c|}{$1,057.476$} \\
\hline \multicolumn{2}{|l|}{ Model $\chi^{2}$} & \multicolumn{3}{|c|}{$309.696^{* *}(\mathrm{df}=6)$} & \multicolumn{3}{|c|}{$458.819^{* *}(\mathrm{df}=9)$} & \multicolumn{3}{|c|}{$629.729^{* *}(\mathrm{df}=11)$} \\
\hline \multicolumn{2}{|l|}{ Nagelkerke $R^{2}$} & 0.271 & & & 0.383 & & & 0.500 & & \\
\hline Homser and Lemes & how $\chi^{2}$ & 8.066 & $d f=7)$ & & 7.468 ( & $f=8)$ & & 5.018 & $d f=8)$ & \\
\hline
\end{tabular}

\footnotetext{
$* p<0.05 * * p<0.01$
} 
likely to be frequent users of public transport than those who evaluate the living standard of their household as average. Whether or not a household has a child younger than 14 years was not statistically significant regarding the odds of being a frequent user of public or car-only transport.

The coefficient of determination after the second step, which also includes the variables that refer to the possibility of taking a trip by public transport, increased by 0.112 . Out of the three variables additionally included in this step, only the distance of public transport stops from residences was not a statistically significant predictor, whereas the two other variables were statistically significant predictors of being a frequent user of public or car-only transport. The regression analysis showed that people who live in towns with more than 75,000 citizens and those whose usual destination is accessible by public transport are more likely to be frequent users of public transport.

In the third step, in which the variables that refer to the possibility of taking a trip by car transport were included in the model, the coefficient of determination increased additionally by 0.117 . In this final model, the results show that five out of nine variables statistically significantly influence the likelihood of being a frequent user of public or car-only transport. In this step, among sociodemographic and socioeconomic variables, only age was a statistically significant predictor. People between 30 and 64 years of age are $83 \%$ less likely and people older than 64 are about $78 \%$ less likely to be frequent users of public transport than people in the age category of 14 to 29 years. So after controlling for the effects of availability of car transport, the association of both gender and household living standards with transport mode preferences did not persist. Furthermore, the regression analysis revealed that out of three variables that refer to the accessibility of public transport, only settlement size and accessibility of the common destination via public transport were statistically significant predictors of being a frequent user of analysed transport modes. More precisely, people who live in larger urban centres (with more than 75,000 citizens) are 5.6 times more likely to be frequent users of public transport than those who live in towns with fewer than 75,000 citizens, and people who have usual destinations accessible by public transport are 2.8 times more likely to be frequent users of public transport than people whose usual destinations are not accessible by public transport. Also, both independent variables that refer to the availability of cars have been statistically significant predictors of the frequent usage of analysed transport modes. People from households that have two or more cars at their disposal are 33\% less likely to be frequent users of public transport than people who come from households with one available vehicle. Even more pronounced differences in the likelihood of frequent usage of public or car-only transport referred to whether the person is the main driver of the car in the household; people who are the main drivers are about $87 \%$ less likely to be frequent users of public transport than those that are not the main drivers in the household.

\section{DISCUSSION}

The analysis performed in this paper was focused on the transport mode choice preferences, particularly on the interrelation of public and car transport use in the Croatian society. More precisely, the main aim of the analysis was to obtain insight into the factors that influence the preferences for using these two modes of transport and to find out how high or low the possibility of taking trips by public or car-only transport affects the likelihood of being a frequent user of one of these two transport modes. The performed analysis offers several basic insights.

First, people who have at least the theoretical possibility of choosing between using public and car transport more rarely chose public transport. Moreover, the ratio of the probability of being frequent users of these two modes of transport reveals that the Croatian society is still rather highly dependent on the automobile.

Second, the bivariate analysis showed that the majority of analysed variables produce statistically significant differences in the frequency of usage of public and car transport; the difference in preferences of these two transport modes regarding the subjective evaluation of household standard of living was not statistically significant. Considering the transport mode choice preferences, especially interesting is the finding that out of all the independent variables, only the age variable and only in the 14-29 age category, the number of frequent users of public transport exceeded $50 \%$. In other words, in all other categories, the majority of respondents were those who rely more often on car-only transport. This imbalance in favour of frequent usage of car-only transport reveals that a large number of Croatian citizens do not regard car and public transport as compatible, but rather as mutually competitive transport modes. It seems as if, to many people in Croatia, public transport is an option used only out of necessity. However, this is not the case specific to Croatia only. More specific analysis of the transport mode choice stressed that the frequent usage of cars is mostly a consequence of habit and inertia, and not of some rational deliberation of advantages and drawbacks [22].

Third, the results of hierarchical binary logistic regressionanalysis reveal that both the possibility oftaking trips by public transport and the possibility of taking trips by car transport are related to the frequent usage of these transport modes. In the last step, in which the predicting power of all three blocks of variables 
was analysed, and for which the analysis showed that it has a great effect on the outcome of the dependent variable, five out of nine independent variables were found to be statistically significant predictors. In the regression model adjusted for all nine variables, whether the person was the main driver of the household car had the strongest effect on the likelihood of being a frequent user of public or car-only transport. Besides, the age of the respondent, whether the respondent lives in larger urban settlements, the accessibility of usual destinations by public transport and finally the number of cars in the household also had statistically significant effects on the analysed transport mode preferences.

It was mentioned that the preferences of frequent usage of public or car-only transport were affected by variables that refer to the possibility of taking a trip by these transport modes. A separate introduction of these two elements into the hierarchical regression analysis - the possibility of taking a trip by public transport in the second block and the possibility of taking a trip by car transport in the third block - produced an almost equal change in the coefficients of determination, which indicates the balanced importance for forming the preferences for the frequent usage of analysed transport modes.

Furthermore, the regression analysis showed that there are also differences in frequent usage of public or car-only transport among age categories of the population regardless of the level of accessibility of these two transport modes. People between the ages of 14 and 29 , namely, are much more likely to be frequent users of public transport than respondents older than 30. This finding was not unexpected since the use of public transport is often a question of convenience. Public transport very often means crowds and standing in the vehicle, so it is no wonder that if there is a possibility of choice, this transport mode is less interesting for older adults and the elderly [23]. Besides convenience, some studies showed that attitudes towards transport mode use [24] as well as social status-related attitudes are predictors of transport mode preferences [25], which could also explain the strong car-only use habit among older adults and elderly people in our study.

\section{CONCLUSION}

The analysis has shown that the number of people who frequently use public transport is much lower than the number of frequent users of car transport, and the number of frequent users of public transport varies substantially among certain categories of respondents. The preferences regarding frequent usage of public or car-only transport is affected by the age of respondents, where they live, the accessibility of usual destinations by public transport, number of vehicles in the household and whether the person is the main driver of the household car.

The findings indicate that in considering the traffic issues, one should consider that personal trips are not just determined by technical and/or economic parameters but by the social dimension as well. One should also take care about who travels since different categories of citizens obviously have different trip patterns. Such findings are in accordance with the results of similar studies that focus on the influence of different factors on the usage of car transport [26].

The introductory part pointed out the connection between the mode choice and mobility. Mobility is an extremely important component in the lives of people, and the transport mode is an important factor in the approach to various living activities and needs. Since in the Croatian scientific bibliography there are rare and only partial studies that refer to the transport mode choice, attention needs to be paid to the intensive implementation of different studies within the frame of influence of different factors on the transport mode choice as well as the influences of transport mode choice on the everyday lives of people. The results of these studies can find their place in the spatial, transport and social planning. There is a special need to study the influence of transport mode choice on the everyday living of transport disadvantaged social groups and spaces where they live. Only systemic dealing with this topic will make it possible to increase the awareness of people about these types of inequalities in the society, and thus also detect the possible measures to reduce the transport disadvantage, as well as potential social exclusion and the improvements of the quality of life, with the end goal of achieving transport and overall social justice [27].

Finally, we should not forget the issue of the environmental impact of mode choice since the transport sector is the second largest source of greenhouse gas emissions (after energy production) [28, 29, 30]. Our finding about the predominance of car-only users (over public transport users) indicates a shortfall in the development of a sustainable transport system in Croatia. So in order to facilitate the policies that promote sustainable mobility, future studies should also focus on environmental aspects of the mode choice.

\section{ACKNOWLEDGMENTS}

The analysis presented in this paper is based on data collected for the development of the National Transport Model for the Republic of Croatia. The project is co-financed by the EU from the European Regional Development Fund under Transport Operational Programme 2007-2013. The beneficiary of the 
project is the Ministry of Maritime Affairs, Transport and Infrastructure of the Republic of Croatia. Any opinion, finding, and conclusion or recommendation expressed in this paper are those of the authors and do not necessarily reflect the opinion of the European Union.

\section{Dr. SC. GERAN-MARKO MILETIĆ ${ }^{1}$}

E-mail: geran@pilar.hr

Dr. sc. SLAVEN GAŠPAROVIĆ ${ }^{2}$

E-mail: slaveng@geog.pmf.hr

Dr. Sc. TONČI CARIĆ ${ }^{3}$

E-mail: tonci.caric@fpz.hr

${ }^{1}$ Institut društvenih znanosti Ivo Pilar Marulićev trg 19/I, 10000 Zagreb, Hrvatska

${ }^{2}$ Sveučilište u Zagrebu, Prirodoslovno-matematički fakultet, Geografski odsjek,

Marulićev trg 19/II, 10000 Zagreb, Hrvatska

${ }^{3}$ Sveučilište u Zagrebu, Fakultet prometnih znanosti

Vukelićeva 4, 10000 Zagreb, Hrvatska

\section{ANALIZA SOCIOPROSTORNIH RAZLIKA U ODABIRU PRIJEVOZNOG SREDSTVA}

\section{SAŽETAK}

Polazeći od toga da je izbor prijevoznog sredstva zasigurno jedan od onih aspekata prometnih navika koji u velikoj mjeri utječu na efikasnost prometnog sustava, u ovom radu su analizirani čimbenici koji pridonose korištenju javnog automobilskog prijevoza. Ciljevi analize su bili dobiti uvid u preferencije spram korištenja ova dva tipa prijevoza $u \mathrm{Hr}$ vatskoj te doznati u kojoj mjeri na često korištenje automobilskog i javnog prijevoza utječu osnovna demografska i socioekonomska obilježja ispitanika te mogućnost realiziranja putovanja tim prijevoznim sredstvima. U radu su analiziran podaci prikupljeni anketnim istraživanjem na reprezentativnom nacionalnom uzorku. Dobiveni rezultati pokazuju da u Hrvatskoj udio osoba koje često koriste javni prijevoz znatno zaostaje za udjelom čestih korisnika automobilskog prijevoza. Međutim, usporedba je otkrila da udio čestih korisnika javnoga prijevoza znatno varira među pojedinim kategorijama ispitanika. Korištenjem binarne logističke regresijske analize utvrđeno je da na preferencije spram čestog korištenja javnog odnosno automobilskog prijevoza statistički značajno utječu dob ispitanika, tip naselja u kojem stanuju, dostupnost odredišta javnim prijevozom, broj vozila u kućanstvu te je li osoba glavni korisnik automobila u kućanstvu.

\section{KLUUČNE RIJEČI}

mobilnost; putne navike; odabir prijevoznog sredstva; javni prijevoz; automobilski prijevoz;

\section{REFERENCES}

[1] Beirao G, Cabral J. Understanding attitudes towards public transport and private car: A qualitative study. Transport Policy. 2007 Nov;14(6):478-489.
[2] Soltanzadeh H, Masoumi H. The Determinants of Transportation Mode Choice in the Middle Eastern Cities: the Kerman Case, Iran. Journal of Land Use, Mobility and Environment. 2014 Aug;7(2):199-222.

[3] Lukić A, Prelogović V, Rihtar S. Planning a more humane city: Student expectations concerning bicycle use and transportation in Zagreb. Hrvatski geografski glasnik. 2011 Aug;73(1):111-132.

[4] Milković M, Štambuk M. To Bike or not to Bike? Application of the Theory of Planned Behavior in Predicting Bicycle Commuting Among Students in Zagreb. Psihologijske teme. 2015 Jul;24(2):187-205.

[5] Janssen L. Die Zukunft der Stadtmitte? City-Konzept Blaue Zone München. Internationale Verkehrswesen Hamburg. 2004 Apr;45(4):196-203.

[6] Litman T. Evaluating Accessibility for Transportation Planning: Measuring People's Ability To Reach Desired Goods and Activities [Internet]. Melbourne: Victoria Transport Policy Institute; 2007 [cited 2016 Feb 16]. Available from Netlibrary: http://www.vtpi.org/access.pdf.

[7] Halden D. The Use and Abuse of Accessibility Measures in UK Passenger Transport Planning. Research in Transportation Business \& Management. 2011 Nov;2(1):12-19.

[8] Hurni A. Transport and Social Disadvantage in Western Sydney: A Partnership Research Project. Sydney: University of Western Sydney; 2006.

[9] Adetunji MA. Gender Travel Behaviour and Women Mobility Constraints in Ilesa, Nigeria. International Journal for Traffic and Transport Engineering. 2013 Jun;3(2):220-229.

[10] Buehler R. Determinants of transport mode choice: a comparison of Germany and the USA. Journal of Transport Geography. 2011 Jul;19(4):644-657.

[11] Tyrinopoulos $Y$, Antoniou C. Factors affecting modal choice in urban mobility. European Transport Research Review. 2013 Mar;5(1):27-39.

[12] Loo LYL, Corcoran J, Mateo-Babiano D, Zahnow R. Transport mode choice in South East Asia: Investigating the relationship between transport users' perception and travel behaviour in Johor Bahru, Malaysia. Journal of Transport Geography. 2015 Jun;46(1):99111.

[13] Dargay J, Gately D. Income's effect on vehicle ownership, worldwide: 1960-2015. Transportation and Research Part A. 1999 Feb;33(2):101-138.

[14] Timmermanns $H$, van der Waerden P, Alves M, Polak J, Ellis S, Harvey AS, et al. Spatial context and the complexity of daily travel patterns: an international comparison. Journal of Transport Geography. 2003 Mar;11(1):37-46.

[15] Currie G. Young Australians: No Way to Go. In: Currie G, Stanley J, Stanley J, editors. No Way To Go-Transport and Social Disadvantage in Australian Communities. Clayton: Monash University ePress, 2007; p. 08.108.14.

[16] Holz-Rau C, Scheiner J. Travel mode choice: affected by objective or subjective determinants?. Transportation. 2007 Jul;34(4):487-511.

[17] Cervero R, Radisch, C. Travel choices in pedestrian versus automobile-oriented neighborhoods. Transport Policy. 1995 Jul;3(3):127-141. 
[18] Plaut P, Boarnet M. New Urbanism and the Value of Neighbourhood Design. Journal of Architectural and Planning Research. 2003 Sep;20(3):254-265.

[19] Cervero R. Built environments and mode choice: toward a normative framework. Transportation Research Part D: Transport and Environment. 2002 Jun;7(4): 265-284.

[20] Hine J, Mitchell F. Transport Disadvantage and Social Exclusion: Exclusionary Mechanisms in Transport in Urban Scotland. Surrey: Ashgate; 2003.

[21] Banister D. Unsustainable Transportation. New York: Routledge; 2005.

[22] Davidov E. Explaining Habits in a New Context the Case of Travel-Mode Choice. Rationality and Society. 2007 Aug;19(3):315-334.

[23] Rosenbloom S. Mobility of the Elderly: Good News and Bad News. In: Townes MS, editor. Transportation in an Aging Society: A Decade of Experience. Washington, DC: Transportation Research Board; 2004. p. 3-21.

[24] Popuri Y, Proussaloglou K, Ayvalik C, Koppelman F, Lee A. Importance of traveler attitudes in the choice of public transportation to work: findings from the Regional Transportation Authority Attitudinal Survey. Transportation. 2011 Jul;38(4):643-661.
[25] Şimşekoğlu Ö, Nordfjærn T, Rundmo T. The role of attitudes, transport priorities, and car use habit for travel mode use and intentions to use public transportation in an urban Norwegian public. Transport Policy. 2015 Aug;42:113-120.

[26] Johansson MV, Heldt T, Johansson P. The effects of attitudes and personality traits on mode choice. Transportation Research Part A. 2006 Jul;40(6):507-525.

[27] Shirmohammadli A, Louen C, Valée D. Exploring mobility equity in a society undergoing changes in travel behaviour: A case study of Aachen, Germany. Transport policy. 2016 Feb;46:32-39.

[28] Bigazzi AY, Broach J, Dill J. Bicycle route preference and pollution inhalation dose: Comparing exposure and distance trade-offs. Journal of Transport \& Health. 2016 Mar;3(1):107-113.

[29] Chow ASY. Spatial-modal scenarios of greenhouse gas emissions from commuting in Hong Kong. Journal of Transport Geography. 2016 Jun;54:205-213.

[30] Nocera S, Cavallaro F. Economic valuation of Well-ToWheel $\mathrm{CO} 2$ emissions from freight transport along the main transalpine corridors. Transportation Research Part D: Transport and Environment. 2016 Aug;47: 222-236. 